Copyright ( $) 2016$ SCAD Independent

All Rights Reserved

Printed in the Indonesia
Jurnal Ilmiah Peuradeun Vol. 4, No. 2, May 2016

\title{
PARADIGM SHIFT IN OPEN EDUCATION AND E-LEARNING RESOURCES AS TEACHING AND LEARNING IN PHILIPPINES
}

\author{
Mellissa Acosta \\ University of the Philippines Diliman, Quezon City, Philippines \\ Email: mlissa_costa@yahoo.com
}

Received: Sep 23, 2015

Accepted: Dec 2, 2015

Published: May 28, 2016

Article Url: https://journal.scadindependent.org/index.php/jipeuradeun/article/view/94

\begin{abstract}
Education has over the years moved from one stage of development to the other with its peculiarities and challenges. There have also been series of innovations, strategies and policies based on the changes in the society. Some of these changes require technological approach which usually poses challenges because the country, like other developing countries, is ill-prepared and unable to immediately address each educational challenge as it appears. The paradigm shift, general acceptance of the new move or model in global technological education, government policies and massive enrollment for e-education and e-learning by the learners, the attitudes of all concerned in the design and full implementation of ICT and e-learning policies in education should be sustained. Some of the students and even the teachers or facilitators may still prefer the print materials which may limit their knowledge, effectiveness and resourcefulness with time. As a result, there is an increase in demand for a more flexible and cost effective means of education through e-education, e-learning or open and distance learning. This has brought a paradigm shift on how people generally view the significance of e-learning for higher education in Philippines.
\end{abstract}

Keywords: Education, Teaching, effectiveness, e-learning, Philippines 


\section{A. Introduction}

Education has over the years moved from one stage of development to the other with its peculiarities and challenges. There have also been series of innovations, strategies and policies based on the changes in the society. Some of these changes require technological approach which usually poses challenges because the country, like other developing countries, is ill-prepared and unable to immediately address each educational challenge as it appears. Since it is becoming increasingly difficult to obtain admission into higher education due to population explosion, poverty, ignorance, and so on, the introduction of Open and Distance Learning (ODL).

As the learning technologies are mushrooming and becoming more and more inexpensive and widely accessible, the modes of teaching, learning and education delivery are going through significant changes. There are paradigm shifts in different dimensions of e-learning and the environment around it.

E-Learning or e-Education has brought a paradigm shift from the way learners view e-learning because some who have privately and individually sought to obtain degrees awarded through correspondence education by overseas institutions in the past, can now use the opportunities provided through e-learning education in Philippines.

In the early days it received a bad press, as many people thought bringing computers into the classroom would remove that human element that some learners need, but as time has progressed technology has developed, and now we embrace smartphones and tablets in the classroom and office, as well as using a wealth of interactive designs that makes distance learning not only engaging for the users, but valuable as a lesson delivery medium.

Traditionally, students used transmissive modes of learning, however, now there are shifts from content-centered to competency-based curricula as well as departures from teacher-centered delivery to student-centered delivery where students are encouraged to take on the driving seat for their own learning (Oliver, 2002). There are shifts from objectivism to constructivism, technocratic to reformist and holist paradigms, and from instrumental uses of ICT to their substantive role (Aviram \& Tami, 2004). The knowledge is becoming a central economic driving force, with the shift from the concept of 'information society' to that of 'knowledge societies' demanding the reevaluation of the existing traditional educational 
processes and the role and training of teachers in the light of emerging ICTs (Loing, 2005). These paradigm shifts are changing not only the way of computing but also how the society perceives technology itself (Kundi \& Nawaz, 2010).

According to Simiyu (1999), while correspondence education utilized print materials majorly, distance teaching or e-learning has incorporated a variety of media, especially information and communication technology resources to achieve its educational results. Open and distance learning and elearning incontrovertibly provide the most effective, flexible and cost effective means of operationalizing the learning paradigms which the contemporary knowledge demands. The open education, e-learning and ICT are inseparable especially when we consider some definitions of open education resources and that the resources for open education and e-learning are powered by ICT.

D'Atoni (2007) describes open education resources as technologyenabled, open provision of educational resources for consultation, use and adaptation by a community of users for non-commercial purposes. These resources are typically made freely available over the web or the internet, and the principle used is by teachers and educational institutions to support course development, but they can also be used directly by students.

Furthermore, open education resources can also be referred to as digitalized materials, offered freely and openly for educators, students and selflearners, to use and re-use for teaching, learning and research. Other researchers such as Geith \& Vignare (2008) describe open education and e-learning resources as teaching, learning and research resources that reside in public domain which grant freedom to share, reprint, translate, combine or adapt such resources.

\section{B. Stages in the Operations for Teaching and Learning}

The utilization of information and communication technology resources generally display three stages that can be adapted for any form of the educational systems - formal, informal, e-education or e-learning - especially as they relate to the teaching and learning processes. These are as discussed below:

\section{Information and Communication Technology (ICT) Input}

ICT input refers to the acquisition, assimilation or absorption of issues, knowledge, messages and skills relating to ICT which are capable of making 
teachers more competent and effective. The input enables the individual to be functional, to maintain and influence the behaviors of the learners. This process also involves collecting, gathering or seeking information from researches and sources of information. The new media (such as the telnet, the file transfer protocol (FTP), the electronic mail (E-mail)) are examples of the various means of achieving the input aspect of ICT (Adegbija, 2000). The conventional media such as the television, slides, filmstrips, videos, audio formats, visuals, are also good sources of receiving ICT input. At the local level, researches show that elearning generally has its input through facilitation, print media, audio media and rarely through other more sophisticated media in most developing countries (Karuna \& Roy, 1991; Adegbija, 2011).

\section{Information and Communication Technology (ICT) Processing}

ICT processing refers to the documentation of information for e-learning. It is concerned with how current and effective the information from ICT input is; how to update and improve on the information or the data bases given. According to Thayer (1968), information processing deals with evaluation (especially summative evaluation) of received information. This may involve indexing, categorizing and transformation. Evaluation at this instance can be achieved by possibly comparing past developments in ICT with the current ones. This enables users of ICT for any form of education to be able to interpret, expand and convert information received for their educational purpose and situation.

ICT processing also involves storing of information with the aid of files keeping, books, journals, memorizing and visuals in the study centers. In the new technologies storing of information can be achieved with the use of computer systems, World Wide Web (www) site, recordings (videos, audios, etc.), slides, filmstrips, gophers and so on.

\section{Information and Communication Technology Output}

Accordingly, ICT output refers to all the activities performed by individuals and e-learning providers for the dissemination of scientific information for their e-learners. This is made possible if the input and process stages are adequately managed. The three stages are very important and they are dependent on each other. In short, one can rarely do without the other. That is why people often say that you can only give out what you have. ICT 
output can be successfully achieved through the use of appropriate media. Also the new media, such as the computers, e-mails, www, virtual or e-library, the gophers and the Internet are examples of excellent means of ICT output.

\section{Approaches to ICT}

The implementation of information and communication technology sources should be planned in such a way as to ensure that the input, processing and output are attainable for the general objectives of eeducation as a whole. The following approaches should therefore, be considered when planning for ICT for e-learning:

1. Participatory-oriented approach

ICT is a multi-level process of communication involving a variety of senders and receivers of ideas, knowledge and materials. This will make them see it as not merely foreign ideas imposed on them, or a difficult venture but will be like partners in progress with all other stakeholders of ICT that are committed to moving e-education forward (Adegbija, 2000).

\section{Mobilization/ Motivation-Orientated Approach}

This approach involves propelling learners into participating in the use of ICT devices adequately for their studies, assignments, tests and examinations which are usually electronically delivered. Mobilization is a full blown functional education through the use of technological devices. Even though Clark (1983) claimed that media do not only fail to influence learning, one can count on Salomon (1984) who argued that the new cognitive theories attribute motivation to learners' beliefs and expectation about their reactions to external events. Motivating learners to use ICT materials in the teaching and learning processes will in turn help to motivate their learner.

\section{Communication-Oriented Approach}

The communication approach is concerned primarily with the use of ICT to improve the effectiveness of communication skills in education. This approach when taken to the negative extreme will be like the claims of Clark (1985) that media are mere vehicles that deliver instruction but do not influence students' achievement any more than the truck that delivers our 
groceries causes changes in our nutrition. Undoubtedly, communicationoriented approach nonetheless, brings more humanistic attitude to education because of the skills developed for improving human relationships through development and acquisition of communication skills. This approach can also be achieved through the use of m-learning.

\section{Implementing and Monitoring of ICT for e-Learning}

The importance of the implementation and careful monitoring of ICT resources for e-learning needs some emphasis at this juncture. The following are steps needed for proper implementation and monitoring of ICT resources which can be adapted for e-learning:

1. Audience Analysis

ICT should be purposive, problem-oriented and participatory-oriented and should focus on a specific issue or recommended technology. Thus, audience analysis should be carried out using techniques such as Knowledge, Attitude and Practice (KAP) survey regarding innovations being proposed for the use of ICT in education. Information gathered through this can reveal the message design, the most appropriate media or channels to use, how and when to use them.

\section{Objectives of ICT}

The objectives should be specific and based on e-educational or elearning felt needs and directed to solving problems identified through the audience analysis.

\section{Strategies of ICT}

An educational strategic planning approach should be developed with the aim of solving problems that may be responsible for e-learners noninvolvement, inappropriate or discontinued use of ICT media in learning. This can also be applied to the process of target audience segmentation, technology or multi-media selection, information positioning and design, educational materials packaging, development and production, with a view to obtaining maximum (information input, process or output) impact with the least or minimum efforts, time and resources. 


\section{Evaluating ICT}

Formative evaluation in the form of e-assignments, e-courseware and pre-testing of prototype multi-media or educational materials should be conducted before ICT resources are produced en-mass. Formative evaluation is usually referred to as a corrective level of the process of evaluation. Summative evaluation on the other hand, helps to appraise or access the progress of implementation and impact of ICT on education and results are used to improve the overall effectiveness and future replications.

\section{Social-cultural factor}

Accessibility to regular information and messages is important from sociological as well as geographical perspective since learners are not confined to a classroom setting, but are learning from different locations. Even though culture is dynamic, technologies should be made compatible with the cultural domain of learners and the society as a whole. Globalization is in vogue now. However, the cultural dimension should be considered when dealing with the message design, development and production of ICT materials for e-learning.

\section{Economic/Financial}

The profitability and economic gains of the use of technology is the most important factor that will ensure continued use especially by the learners. Economic issues that are related directly or indirectly to cost of technology and service delivery systems and the economic viability should also measure technology in terms of social costs and benefits. This makes e-learning more cost effective, affordable, acceptable and attractive.

\section{Institutional factors}

The type of government support for the institutions that are involved in the generation and transfer of technologies can also affect the use of such technologies. Inadequate institutional arrangements and capacity to carry on educational or project activities without outside supports may be detrimental to the efforts of ensuring sustainability of results achieved (Mangstl, 1998). 


\section{E. ICT and e-Learning education in Philippines}

Information and communication technology (ICT) is the practical offshoot of Educational Technology which by definition is the study and ethical practice of facilitating learning and improving performance by creating, using and managing appropriate technological processes and resources (Januszewski \& Molenda, 2008). If we marry this definition with the definition of e-learning which is the use of internet and digital technologies to create experiences that educate our fellow human beings (Horton, 2005), we will be able to create a complete and perfect approach to the art of teaching and learning at all levels of Philippines e-educational system. The main ingredients for the e-education according to Abimbade (2006) are:

1) IT Policy and ICT infrastructure

2) Trained teachers and support personnel

3) Appropriate computer studies curriculum

4) E-learning hardware and software protocols

The major objectives of the e-education or e-learning in Philippines are to:

1) Enhance access to quality education through e-education/elearning

2) Improve the education delivery system

3) Ensure optimal utilization of existing ICT resources

4) Ensure a globally competitive education system

5) Reduce/eliminate social vices

From the foregoing, one can conclude that ICT is e-learning and elearning is ICT. E-learning in particular cannot exist without ICT except by print technology only which may not exhibit the needed interactive mode provided by ICT. ICT is an essential delivery source of educational resources globally. It is a means of transferring, storing, retrieving and sharing information and resources world-wide.

Unfortunately, despite the advantages of ICT being enjoyed by the developed countries, the developing countries are still lagging behind in the development and utilization of ICT in education. According to research, at least 300,000 new users in the United States of America get connected to the Internet 
daily (Awake, 2002). At least $80 \%$ of all employments in the U.S.A. would have been computer related. While we lack correct figures to show where Philippines stands in ICT development and implementation. No wonder e-learning in Philippines is still far behind the developed countries and other countries such as India, Turkey, Tanzania, and so on.

\section{F. Challenges to the implementation of ICT in e-learning}

Though there is the popular assumption that e-learning is still at the embryonic level of development, there is a strong indication that e-learning is no longer a new idea in principles but its implementation, application or practice is still far below expectation in most developing countries, especially Philippines. However, e-learning can be used as the main approach/strategy for disseminating instructional packages whereby learning takes place solely through electronic contacts and packages (software and hardware). Also, elearning can be used as a combined strategy in which case learning is presented electronically as well as with the conventional face-to-face mode of teaching.

The full implementation and practice of ICT for e-learning in Philippines are plagued with several challenges that are too numerous to mention here. However, we shall try to highlight the challenges from two major categories of perspectives that is; from the Government perspective and other stakeholders in the educational sector:

Government perspectives - The government is the most significant and influential stakeholder in education worldwide. As already indicated, both ICT and e-learning are not new to Philippines or the developing countries, but the main issue is the inability of the governments to implement or cause the implementation of the policies made with regards to ICT and e-learning. Policies and initiatives taken in most cases never saw the light of the day. Even where it appears a particular government is doing something, lack of continuity of government policies truncates the policies. In addition, the emphasis placed on education in Philippines can be described as being 'myopic' because the government makes policies based on the present situation without paying regards to the consequences for the future generations (Adegbija, 2011). There are hardly any projections for moving the educational system beyond this decade. This explains why the standard of education is stagnant or rather falling and cannot meet with the standard of the present technological pace globally. 
There is still a lot to be done to properly sensitize the individual stakeholders to fully grasp the importance and relevance of ICT resources in e-learning or open and distance learning systems. The involvement of the stakeholders in the design, implementation and evaluation of ICT resources used in e-learning cannot be overestimated. Stakeholders and individuals are to be involved as it is practiced in the developed countries. For example, the major custodians, producers and evaluators of ICT tools or resources are individuals or groups such as the Apple by Steve John, Microsoft by Bill Gates, Paul Allen, etc. All these made personal computers and other technologies accessible to individuals, companies, institutions and governments. These personal computers allow and provide applications through the Internet for e-education, e-learning, e-banking, e-communication, e-shopping, e-medicine, etc.

In addition, the need to raise the awareness level of the relevance of ICT resources in e-learning cannot be overemphasized (Olakulehin, 2010). A shift from looking up to high-technology as the only resource for disseminating e-learning is necessary. As Romiszowski (2010) observed, high quality of learning may not necessarily correlate closely with high technology. Simple, day to day technologies which Osuyi (2006) referred to as m-learning, that is, mobile technologies should also be employed in learning and teaching. These mobile technologies include - mobile phones, handhold computers, tablet computers, PDAs, Smart phones, laptops, electronic papers, MP players, personal response systems, USD sticks, digital voice recorders, digital camcorders, portable DVD player. According to the observation of Romiszowski (2010), excessive emphasis on technology as the solution on " $\mathrm{E}$ " in e-learning especially in the Philippines environment where technological expertise or manipulation is not good enough, may be a part of the problem in the developing countries. He opined that the reuse of e-learning objects facilitated by poor standards may promote the easy replication of past instructional design blunders and may contribute to a general lowing of educational quality.

Also, the teachers and students who are the main consumers of ICT resources in the educational system need to be more computer literate in order to sustain and encourage the current zeal or paradigm shift and because there is no short cut to implementing ICT in e-learning education as a whole. 


\section{G. Conclusion}

General acceptance of the new move or model in global technological education, government policies and massive enrollment for e-education and elearning by the learners, the attitudes of all concerned in the design and full implementation of ICT and e-learning policies in education should be sustained. Resistance to change is a factor which prevents the full implementation of ICT in the classroom and this type of resistance can also affect users of e-learning or e-education resources. Some of the students and even the teachers or facilitators may still prefer the print materials which may limit their knowledge, effectiveness and resourcefulness with time.

Information and communication technology (ICT) is said to have progressively repositioned the way knowledge and information are directed towards achieving educational goals through the operations of open and distance education, e-education, e-learning, m-learning, and so on. By definitions and practice, ICT and e-learning are inseparable but dependent on each other for effective learning. There are challenges militating against the full implementation of ICT in e-learning education and these were discussed from the perspectives of the government and other stakeholders in the Philippinesn educational system.

\section{Bibliography}

Abimbade, Alade (2006). ICT in education: teacher preparation and quality assurance in Africa. Journal of e-Learning (JOEL), 2(1), 118.

Awake (2002). The technology behind globalization. 22, 5.

Clark, R. E. (1983). Reconsidering research on learning from media. Review of Education Research, 43 (4), 445-459.

Clark, R. E. (1985). Absolutes and angst educational technology research: A reply to Don Cunningham. Educational Communication and Technology Journal, 34 (1) 8-10.

Da'Antoni, S. (2007). Open educational resources: the way forward. Deliberations of an International Community of Interest. Paris: UNESCO-IIEP.

Geith, C. Vignare, (2008). Access to education with online learning and open educational resources: can they close the gap? Journal of Asynchronous Learning Networks, 12 (1). 
Horton, W. (2005). Leading e-learning U.S.A. Colorado. American Society of Training and Development. http://www.astd.org

Jegede, O. (2010). A dream tempered with reality. NOUN update. Directorate of Media $\mathcal{E}$ information, (1)3.

Karuna, K. \& Roy, S. (1991). Communication network for food consumptionpractice. Indian Journal of Extension Education, 27 (3\&4), 76-78.

National Universities Commission (NUC), (2006). Weekly (Monday) Bulletin. September 19

Osuji, U.S.A. (2006). Open \& distance education \& e-learning. Journal of eLearning (JOEL), (2)IJ,15

Romiszwoski, Alex (2010). Educational technology, distance learning and instructional design: A personal perspective on origins, progress and prospects. In Paul A. Ifeanyi \& Felix K. Olakulehin (eds). Global Perspectives in Open and Distance Learning. Lagos: National Open University of Nigeria.

Rosenberg, M.J. (2001). E-Learning. New York: McGraw Hill Publishers.

Saifullah. (2015). The Internalization of Democratic Values into Education and Their Relevance to Islamic Education Development (Synthetic, Analytic, and Eclectic Implementation of John Dewey's Thoughts). Advanced Science Letters, Journal of Computational and Theoretical Nanoscience, 21 (7), pp. 2301-2304, DOI: 10.1166/asl.2015.6257

Salami, S. (2015). Implementing Neuro Linguistic Programming (NLP) in Changing Students' Behavior: Research Done at Islamic Universities in Aceh. Jurnal Ilmiah Peuradeun, 3(2), 235-256.

Salomon, G. (1984). Television is easy and print is tough. Journal of Educational Psychology. 6, 647-658.

Simiyu, A.M. (1999). New and emerging technologies in teaching and learning in higher education. Lead presentation at the regional workshop on teaching and learning in higher education. Moi University, Eldoret, Kenya.

Yusoff, M. Z. M., \& Hamzah, A. (2015). Direction of Moral Education Teacher To Enrich Character Education. Jurnal Ilmiah Peuradeun, 3(1), 119-132.

ZA, T. (2014). Islamic Studies dalam Pendekatan Multidisipliner (Suatu Kajian Gradual Menuju Paradigma Global). Jurnal Ilmiah Peuradeun, 2(2), 211-234. 